\title{
An introduction to Concepts of Justice in Islam
}

\author{
Dr. Mohammad Reza Akhzarian Kashani \\ Faculty member, Center for the Study of the Islamic Revolution, \\ University of Tehran
}

\begin{abstract}
Conceptual justice is so broad that, at the same time, apparent simplicity is associated with many complications, and thinkers, philosophers, economists, and lawyers ... have more than two thousand years ago still sought to find the right meaning. The concept of justice is understandable and desirable for most human societies, and this utility and importance for Muslims has been doubled. One of the ideological questions and ideals of Islamic thought was the concept of justice, which had a high status in Islamic thought and undeniable role among the Shi'ites as one of the largest Muslim groups. This paper seeks to clarify, at the same time, a comprehensive and thorough explanation of their idealistic approach to justice by examining the most important principles and concepts of justice from the Muslim perspective. On this basis, justice is considered from a number of perspectives, and the approach of the Quran as the main source of Muslims, as well as the approach of Muslim theologians and Muslim jurists.
\end{abstract}

Key words: justice, Islam, Shiism, theology, jurisprudence

\section{INTRODUCTION}

Justice is one of the issues that human beings have in nature and human nature, inspired by virtue of piety and authority. The category of justice is a very broad concept which, at the same time, has been apparent in its simplicity, with many complications, so that Plato's book of republicanism with the question "What is justice?" And yet with today's more than two thousand years, the concept of justice remains unclear, and thinkers, philosophers, economists and lawyers ... are still looking for the right meaning. Justice is among the key concepts of the field of politics as an abstract concept, although it can not easily be provided for foreign exchange, but for most human societies, it is understandable and desirable. On the other hand, contrary to many of the common concepts in the political and philosophical domain, which have not had much credibility, there is a great deal of justice in the concept of justice, and it has been the concept of a stable political thought that has engendered the minds of many scholars.

\section{THE IMPORTANCE OF JUSTICE IN ISLAM AND SHIISM}

One of the ideal questions of Islamic thought is the concept of justice, which has had a great place in Islamic thought. So that one of the most controversial, most dynamic and most important topics of interest to thinkers, theologians and Islamic philosophers has been the concept of justice and has been dealt with in various Islamic scholarly schools for many years. The importance of justice in Islam is to a degree that considers justice to be divine attributes and conditions without which the divine being will not be complete and, accordingly, Muslim thinkers will examine the dimensions and aspects of it. This tendency and attention to the notion of justice in the Shiite thought is considered to be superior to the Shi'ah as one of its religious and religious principles, and considers the rejection of it as an exclusion from the Islamic religion and at the level of disbelief and apostasy.

In Shi'a thought, justice is one of the most important issues, from which lay people to 
properties and thinkers to their dominant rulers. Shi'is consider the purpose of the Prophet's government as the fulfillment of justice and justice in the international community and considers Ali (AS) the first martyr of justice and considers the duty and mission of the Imams as the fulfillment of divine justice, and the emergence of his last savior from the Imams Shi'a (AS) is designed to revive justice in a society full of oppression and the world. Throughout Shia's political history, Shiites have raised the flag of justice whenever Governments have oppressed the sword, and Shiite leaders have made the greatest human epic with a cry of justice.

However, the category of justice is still not fully understood and there is no consensus among the general public on its introduction.

It is less a society that does not speak of rights and law and justice, and it is less a government that does not protect itself as the rights and interests of society. However, every state and society faces some basic questions. Including which law can be $100 \%$ fair? And fair laws are laid down according to which criteria, and even on the assumption of different legislators' different dependencies, it is possible to consider all aspects of human beings / so that legislative and planning planning should be done by a system that can be used to identify the benefits of human beings. A system that meets the criteria of human nature. It is true that Islam, which has laws that are in line with human nature, claims to be the best and most commendable laws, and is committed to such an obligation that it is the duty of the righteous to assume responsibility for all key positions of society, and that the condition of justice is a prerequisite for their acceptance. From Imam Jamaat and Friday to Judge, witness, Imam Ali, leader and battalm all must be fair and if this condition is not met, the responsibility is not attributed to them and is considered to be unusual, usurper and ruthless servant. In short, Islam attaches great importance to justice, and it is a fundamental condition in the wisdom of society and in all legal, social, family and economic matters.

The great philosophers for justice have identified four basic principles and called them natural rights. Based on this, each law and the Shari'a which has the following four principles and show them more, bring with them a greater share of justice. The first natural right of man is the right to life, which is why no one is allowed. This natural right Take him away from him. This right is the source of other rights, including the defense of life.

The second natural right of a human being is the right to live in the form of a creature of wisdom, and the community is obliged to allow man to use this natural aptitude. The third natural right of a person is the right to freedom of choice of labor and the use of land and ... and to the extent that each person can use the earth and all that is created in it, and no one has the right to remove him from his activities and possessions Unless his activity and capture entail a violation of other rights. The fourth natural right of a person is the right to equal every person with other persons in the law so that the ruler and the people, the rich and the poor, are equal before the law and in the exercise of their legitimate rights.

Any law and law that holds these qualities and complies with these principles of natural law has a higher percentage of justice, and that law and the law will be fairer, and the law that does not include them will be incomplete or ruthless.

Islam, as the last celestial religion, firstly has given particular attention to the right of life, and the Islamic law has been more than just the right to respect and protect this right. The Holy Quran has considered the murder of the soul without the legal permission of the greatest sins: Vla ta'tatlvavn al-Yuli, the Holy Prophet (pbuh), and the punishment of such a murder is 
considered the eternal punishment of hell: and I am convinced that the fault of Hell Khalida Fiha and the Prophet of Islam (pbuh) The maintenance of the believer's Muslim life has said: Lazwal al-Daniyah, Ali Allah, the killing of the believers. Secondly, the Sharia of Islam is the first Shari'ah to consider man as a wise, intellectual and intellectual creature, and it is well known that the Holy Qur'an spoke to man and was known to him as a person. He has paid attention to his profit and loss to the point where he is even infallible and idolatrous Lille rational argument will: with God's divine least Hatva Brhankm the Kntm Truthful. Islam values the value of reason and thought from the best of its goals and principles, and has spoken with a human being with an audience of human consciousness and understanding. There are many verses that signify human thought and reasoning.

Thirdly, the religion of Islam has strongly encouraged people to exploit their land and its belongings, and to seek to promote agriculture and commercial and industrial production, and this is due to the encouragement that Muslims in the early days of Islam, with a strange burst of short duration, would all benefit from the civilizations of India and Greece And added Rome and Iran to their new civilization. It is also emphasized in many verses: and the verses of Maknah al-Ma'fi al-Zar and the forefebees of the Faith are worthy. We left your hands on the ground with a variety of grabs and provided the livelihood and livelihood of your life. Or elsewhere, he says: "Allah, Allah, Allah, Allah, Allah, Allah, Allah, Allah, Allah, Allah, Allah, Allah, Allah, Allah, Allah, Allah, Allah, Allah, Allah, Allah and Allah. And eat from the fruits of God that these emphases point to the importance of Islam to work and business and to gain freely that the context has provided to God Himself.

Fourth, Islam does not distinguish between the ruler and the people, the rich and the poor, and the people's classes, both for creation and for the sake of equal rights. Or, these are the signs of my own mind, and the guilty and false accusations, and the tribes of the Lutheran of the Prophet, The combination of these four attributes in Islam has made Islam as a fully coherent and coherent religion establish the most just rules for human life and introduce Islam as a religion with justice to the world.

Islam is a school of justice and moderation. The direct path is the Islamic Ummah of the Middle and Middle Edom, and its system is just, that is, in all aspects of religion, ethics, and rationalism, it is the medium and the moderation. In Islam, the discussion of justice is one of the foundations of moderation, which has very deep roots, such that, firstly, the entire universe is under the control of the wise God and is not chaotic, and therefore the superiority of a person is not so dominant to others. Secondly, all deeds and deeds, and even human thoughts, are under the control of a god who trials everyone in court.

Thirdly, all of the soil is created and returned to soil, and it is not different from the particles of soil, so that it is different from humans.

Fourth, all people are God's servants and equal in bondage.

Fifth, the whole being does not exceed the limits of the divine law.

Sixth, the parents of all human beings are the same.

These fundamentals of thought have made all Muslim people equal to themselves, and Islam equals everyone against their laws and laws. 
Islam has so much importance to justice that in many of the traditions narrated by the infallibles (a) many have been emphasized and even considered as an integral part of Islam.

Among the narratives are the following:

From the Prophet (pbuh), it is quoted, the justice of my goodness, Abadeh Sobin, the Sunrise of the Lilies and the Lions

An hour of justice is better than seventy years of worship, which is the rest of its days and nights. Or else, he said: إم المام العالد في رطية يو مة وأذاء أفضل من العاد العبد در في اله كعة الأرض كثمسين. The action of a day of leadership that treats people among the people of justice is better than one hundred or fifty years of one who is engaged in worship among his people. And Imam Sadiq (as) said: Al-Amam al-Adlat-la-tard el-Dawah never prays the true leader. And Amir alMomenin (AS) said: "Allah's pleasure and peace be upon him, and Allah's will and peace be upon him, and the cause of justice is both expedient to the people, and it is God's approach, and the justice of life and oppression is death." Based on this, the infallibles (a) considered justice to be an integral part of Islam, and they are considered to be of high status.

The Qur'an, as the initial program of Islam, has considered the responsibility of the prophets to establish social justice and, along with the duty of inviting people to obey God and cultivate and teach human beings, ... their duty to form a society whose people revolt in justice and in all relationships Family, social, political, and economic behave fairly.

The purpose of the prophets is to bring faith in God so much in the people and to create such ethical and divine thought in the wisdom of the individual and the society in which the people themselves rise to justice and establish a just society: the inspiration of Arslana, Al-Qaqat alMīzān Alīqā-al-Nās al-Māșān, and because the existence of a just society requires both spiritual power and the need for material power, it is necessary to consider both the book and the volume and the extent to which justice is necessary.

\section{JUSTICE IN THE SCIENCE OF ISLAMIC THEOLOGY}

Referring to the history of science in Islam, one of the first issues of interest to thinkers in this field can be found in the field of verbal issues. The relationship between man and God and the study of the traits of God and the Prophet (PBUH), and then the Shiite Imams, were issues that involved Muslims from the beginning and required them to find an answer to the doubts raised by the enemies of Islam. One of the issues that has attracted Muslims for many years, but for centuries, has been the issue of righteousness and oppression. Whether God has shaped the nature of humans alike or that humans are capable of being able to make their own destiny. The Islamic society, which, for many reasons, quickly entered the stage of scientific thinking, considered the issue of arbitrariness as the first issues discussed.

The Islamic community was a religious community, and in the Qur'an, which is the Muslim celestial scripture, we are dealing with matters of algebra, righteousness, divine power, and rewards and punishments. The same issues led Muslims to pay particular attention to algebra. The discussion of algebra and arbitrariness, unwillingly, raised the argument of "justice" because there is a direct relationship between justice and liberty on one side and alienation and rejection of justice on the other, that is, only if it is possible that the duty, reward and punishment of a fair meaning and meaning will find. Islamic theologians from the very beginning were divided into two groups of Mu'tazilites who were supportive of justice and a group of hadiths (Ash'arites) denying divine justice, which, of course, did not mean the negation of justice from God, but provided a special interpretation of it from the standpoint of the Mu'tazilite It is true that the Lord performs his works according to the standard of wisdom 
and righteousness. In their view, some verbs are in their essence, such as rewards to the righteous and some in their own interests, such as the punishment of the righteous, and the verbs in their essence are different with each other, and the sacred essence of the times of excellence is absolute and complete, absolute and absolute wisdom and righteous. He chooses his work with the benchmark and the scale of justice.

But the Ash'arites believe that the righteousness of the essence of the law does not mean that he follows the rules of the law in the name of the laws of justice, but that he is the source of justice. What he does is justice, not what he is doing. Late justice and oppression is the verb of the Lord. Judgment is not the scale of God's verb. The verb is the Lord of the scale of justice.

These two perspectives, on the one hand, on the one hand, and on the other hand on alibi, have not been able to answer many of the doubts and questions of Muslims with all the arguments that he has presented, and therefore the ground for further development and attention to Shiite thought in this field was provided.

From the Shi'a point of view, it is not algebra, nor devolution, but the al-Amrine principle. From the Shi'a point of view, the will of man is not enough to be delegated to him, and the will of God is not the cause of it, and the wrongdoing is not the cause of the impossible, but God has the ability to give the will and will to mankind to try God's power He obeys or sins and deserves rewards or eagles. On the other hand, his will is limited to God's will, to the extent that the divine goodness accompanies it. Human beings are not independent in their voluntary work and not as a pure instrument, but by divine power and self-control as much as divine will. No to God and to the evil of the angels and the giving of God arises and the disbelievers of God are in favor of the good of one's beliefs or self-serving or infallible.

\section{THE QURAN'S ANSWER TO DIVINE DIVINE BELIEFS}

In the case of justice, there are many doubts and doubts that scholars, theologians and Shiite scholars have come to answer. Many of these misunderstandings are due to God's justice because of the harsh and superficial judgments. Many people, by their perceptions, interpret the interpretation and interpretation of God, and attribute to God the things they think they attribute to God, and because they can not, in many cases, understand the causes of God. In the Qur'an, Allah condemns these superficial judgments and warns humans many times that many of his thoughts are unfounded, and how many things you think are bad, but it is in your best interest.

The Qur'an can be the first foundation for the discussion of justice in Islamic society. The holy Quran sowed the thoughts of justice in hearts and created the concern about paying attention to it in Muslims. The Quran portrayed justice in various dimensions of developmental, secular, moral, and social, and argued that the system of being is based on justice and on the basis of deserving and abilities. The Qur'an, in various verses, rejects oppression explicitly from the Quranic realm, and in other verses it introduces the foundation of creation to justice and justice. And in some verses, he mentions the position of divine authority and authority as the authority of the uprising:

Shahdollah al-Loulah al-Haww al-Mala'ek and Ulwalu'lm Qāem al-Baqāștān, whom the Prophet of Islam cites below: "The power of Almwat and Al-Adq

Allah has also considered the reason for the prophets to be sent to justice in the community: Al-Arsalna Balkbayat and Anzlana Allah al-Maizan 
In the Qur'an, all the principles of the doctrine of monotheism and resurrection, prophecy and imamate are based on the basis of justice, and on this basis, due to the particular attention of the Quran to the issue of justice, which Muslims have shown particular attention to it, and one of the most controversial topics in the The history of Islamic theology was created and made each group view its particular political, social, and psychological background from a special point of view, and various Islamic schools on justice were created.

\section{JUSTICE IN SHI'I JURISPRUDENCE}

Justice in the word means "equator" or "endurance" or is used in both ways. In any case, Murad Shar'e and the scholars and jurisprudents of religion have been advocating justice in various ways. Some people regard justice as a psychological one, which is one of the traits of the soul, and has referred to it by interpreting the qualities of the soul, the state of mind, the sensual authority, the council of affairs, the queen of the soul. A common point in all of this is that this justice strengthens virtue.

Seyyed Mohammad Kazem Yazdi (RA) writes in Uruh al-Toqi's book: Justice is the queen of ethan and obligated to leave. And Sheikh Morteza Ansari (ra) in the thesis consider the same meaning among the famous scholars after the famous Allameh Helli.

Therefore, the definition of justice is a state of mind in man, which kills him towards piety and avoids all sins, and makes man obey manhood.

In the other definition, justice has been considered as non-committing a sin or, in addition, it is not necessary to leave, and others have defined justice as non-committing great sins and insisting on small sins that the scholar Sabzevari and the Allameh Majlesi have chosen the same.

The third definition of justice states that justice is the practical endurance that is based on the psychological state and the dominant queen in the soul; in this definition, for justice, two features are mentioned: first, action and verb means doing all the obligations and leaving all the secrets And lack of insistence on small sins, and the existence of a constant mental and mental state, which is the queen and the body and the sensual state. This definition can be found in the words of Ibn Babawayh, Sheikh Mufti and others.

There are other definitions of justice that are not well-known, such as: Adel is a Muslim who has not been guilty of anything, and that he is a just person who has a good appearance.

According to these definitions, any Muslim is just, provided that it appears to be the cause of the sentence or has not been seen from him. Ibn Jenid and Sheikh have mentioned justice in this sense.

But in general, a number of conditions can be set for the concepts of justice that are presented in different narratives:

1. Beware of sterility and chastity, and protect yourself from being forbidden and committing adultery.

2. Leave the great sins that God has given them to the perpetrators of the fire of hell. Like drinking alcohol, adultery, usury, parody, escape from war and ...

3. Cover all the defects and sins of the people, that is, one does not see him guilty.

4. To participate in prayers of the congregation.

5. Do not lie to people, do not promise and do not wrong anyone.

6. The case is the faithful people. 
7. When people get local research about him, people will say that we did not see anything other than good.

8. Not accused of guilty, traitor and suspicious people.

9. Open chess, gambler, singer of Ghana and listening to it.

In sum, it can be said that a just Muslim is someone who has not been guilty of any crime or if he has been seen to repent and commit himself to the provisions of Islam. The testimony of such a person is accepted and his justice is fixed. Such a person should have the Queen of Justice, and not be guilty of anything in the privacy.

\section{MEANINGS AND TYPES OF JUSTICE}

With regard to the concept of justice, three meanings can be mentioned that various thinkers have addressed it accordingly:

A) "justice" means bananas and intentions: if we consider a set of different components used in it and a particular purpose of that purpose, then there must be certain conditions in terms of the quantity of each component and in terms of the quality of the relation of the components to Observe each other and only if that set can remain. And give her a good effect. This equilibrium can be cited socially, economically, politically, culturally, physically, and chemically. In Islamic law, this sense has been used and the Qur'an has used this meaning for banana, intent and moderation in the creation system. The opposite is meaningless, not cruelty, and therefore those who respond to the meaning of proportionality and disproportionality to the oppression of God have not been very successful. Justice means the balance of the chwume of wisdom and knowledge of God, and Allah, according to the requirements of wisdom and science, includes the extent to which everything is necessary and necessary for the building of anything.

B) The second meaning of justice, the equalization and negation of any discrimination. What is used in moral justice, for example, it is said to be justly righteous, results from this. That is, there is no difference between people, and this means the meaning of justice, that is equal. Of course, this sense of justice does not mean that everyone and everything should be perceived with one eye, which is just the same oppression, but it means that it is treated equally with equal rights, which implies a third meaning of justice. Which comes after this.

C) "justice" means the giving of the whole of the right to the right. In this sense of respect, the desirability and granting to any person the right to what it deserves is the true meaning of righteousness. This justice depends on two things: one of the rights and priorities of the human being is to compare one another with each other and give it some sort of rights and priority. Another is the intrinsic characteristic of mankind, which is created in such a way that it is used in its own work and necessarily a kind of credit thinking, and it helps them to achieve their natural purpose. These thoughts are syntactical and are indicated by diodes and not. This is the meaning of justice and oppression, and in order to respond to the dilemma of divine cruelty, this concept of justice must be recognized.

\section{DIFFERENCE OF JUSTICE AND JUSTICE}

The justice can be examined in various aspects. One view of the concept of justice can be considered as heavenly or terrestrial. Accordingly, justice is, on the one hand, a divine concept that includes how divine acts and divine punishments are committed against humans, and, on the other hand, its ground implication includes the exercise of justice among human beings. In the second sense of justice, justice means that justice and justice in human society can be interpreted as justice, which in many texts has been interpreted as social justice. 
One of the missions and goals of Islam was the implementation of social justice and the revival of individual and social rights of humans. Therefore, the Prophet of Islam (PBUH) and Imams Huda (AS) have emphasized this subject and one of the duties of the Islamic state is to restore justice and justice in Community. In Quranic verses, the concept of justice has been emphasized, and it is highly recommended. Because of the special importance that Islam has given to this issue, the concept of justice can be considered as one of the hotspots between Islam and other religions and schools, so that the goal of the religion of Islam can be described as the realization of justice and justice in the world. One of the fundamental differences between Islam and other religions, such as Christianity, is the particular social system that Islam attaches to it. Unlike other religions, the religion of Islam, contrary to other religions, does not require a religious system for the next, which is necessary for both worlds, and claims that it has presented plans for the happiness of both worlds. The religion of Christianity, which lacks social systems, has sought to improve the soul and soul and isolation from the world, but Islam has adopted a different approach. At the time of its emergence, Islam was seeking power and the formation of a government, and in the early years of its existence, it began to form a government and introduce certain legal and political laws and social laws. Islam changed the attitude of man to religion, and, unlike Christianity, adopted a way appropriate to the prosperity of both worlds and based on the unity of the earth and the heavens to provide individual and social commands.

The religion of Islam is the whole unit that deals with all worship and worship in all its laws, and does not distinguish between any worship and trading rules. This method of Islam made it possible to penetrate the social mentality of all aspects of Islam and create the first firm thought in all aspects of this religion.

From the point of view of Islam, every creature has a ruler in accordance with its destination, and the will it initially originates from it, and then it is preserved and preserved by it, in any creature, has its appropriateness, and the causative advantage of it is also restored to existence. . In terms of Islam, human beings are the unity that their expulsion is to separate from each other, for the sake of coexistence and proportionality, and for the final co-operation they come together in different ways, which is the result of a good community that However, they have the same cooperative unit. Therefore, the principle in Islam is co-operative and it is appropriate for everyone to come out of this principle, and this is also the aim of the divine, and this return of man to the path of co-operation and empathy and proportionality in order to reach God can be searched in the concept of justice. . Therefore, justice in Islam is not just economic, but also a concept that even involves perceptions, methods, and consciences and inner senses.

\section{THE BASICS OF THE IMPLEMENTATION OF JUSTICE}

Islam for the implementation of social justice is based on several fundamental principles that shape the basis of justice in Islam. One of these foundations is freedom of conscience. If social justice is not an intrinsic diagnosis of the desirability of a person and the need for society, and that it will never be realized along with the belief that that justice will lead to a high level of humanity. This does not arise without believing that life is in the hands of God.

It is also necessary for the emancipation and release of the human spirit and conscience of the apparent values of the community. Islam views all the appearances of the community with the view of acceptance, but has set a special place for each and condemned extremism in each one.

Another foundation of realizing social justice is the full equality of humanity. One of the key areas for implementing social justice is that people are equal in different fields. Of course, this 
equality does not mean that everyone is the same in all circumstances, but it means that they are treated equally in terms of inherent dignity and abilities, and those who have a single right to be equal.

The third foundation for social justice is social solidarity. Undoubtedly, without the full cooperation of humans in a society, the realization of social justice is impossible or near impossible. If there is no common sense of justice in humans, there will be no grounds for people's attitudes toward its implementation.

On the other hand, in order to administer justice, it is necessary that, without them, it is not possible to realize justice in the community. These tools are on the one hand inner and conscientious, that is to say, to the soul and to human beings. One of these means is the selfrefining of the soul, through which the person lends money to the righteousness of others. On the other hand, he has felt the fear of God that the punishment of God is one of its instruments, and also gives human beings rewards that they grant to them in the pursuit of justice. Among other things, external means and instruments can be mentioned, including financial laws such as zakat, charity and charity.

In Islam, so much emphasis has been placed on justice and its implementation, and several verses are devoted to this. Including:

God bless you in the name of the people and the wisdom of your wisdom. Let's talk about it. From which it is understood that judging between people and judging between human beings must be accompanied by justice and justice, and God considers this to be fair to behave as good. Or he says: "If you are the guardian of the cono-Qavamin, you will be the martyrs, and you will be blamed for the sins of your martyrs, and you will not be dismayed at all." Which directs the faithful to act in justice and to avoid the air and desire, because following the cravings is a departure from justice, in this verse, the failure to implement the right justice is mentioned by following the air and the hollow.

Or, in another verse, he says: "Or, they say," Allah, and Allah, and Allah, and Allah, and Allah, and Allah, and Allah, and Allah, and Allah, and Allah, and Allah, and Allah, and Allah, and Allah, and Allah, and Allah, and Allah, and His Messengers, The agents of righteousness and proximity to God knows. The Qur'an's emphasis on the concept of justice does not end in these same things, and there are many other verses in this field that matter to you.

\section{DIMENSIONS OF JUSTICE}

Islam has brought justice into the dimensions of human life and not only in judgments that it considers necessary in the most basic social and individual dimensions. Among these areas is the observance of justice in exhortation and criticism, and it is advisable to mediate in defining or criticizing others. Ali (AS) said: "Al-Tha'a'a Baqfir al-Mā'āqāq-ye Mul'qā and 'al-Tekhsīr i am' al-waqāqā-i-Awad. If you are more than meritorious, you will be flattered and flattered, and if you did not have the courage to proclaim to the extent necessary or to be inaccurate or jealous. Or else, he said elsewhere: Ophrafat al-Fala'ma'lamah Yashub Niran al-Laha. Exaggerating the blame causes stinging fire.

Another area is the observance of justice in spending and spending. As one of their attributes has been mentioned in the charity in the praise of the righteous servants, they are referred to as "moderate": welzin adzana naftawa lam yusrafwa and lemmehtirova and kan between zhlq qawama. Or else it comes: Lack of spare parts to the left and right side. Which represents justice in spending and spending. It is also recommended in Islam that you should treat justice in the home, and even though Islam permits polygamy, it is conditional on respect for justice, 
and this is not known if it is not able to enforce justice between spouses. And that's what I'm saying. If you are afraid that you can not treat your spouses with justice, then end up with a spouse.

Another area of justice, which is an important part of human social life, is economic justice.

The economic system of Islam is based on justice and is in such a way that the right of anyone is not lost. It is well known that even for the daily hours of a person's life a fair program has been devised, and has divided it into hours of work and worship and recreation, which is why it has been introduced to meet the material and spiritual needs of mankind. Or ordered the provision of justice and equality for the distribution of community facilities. As Ali (as) orders Malek Ashtar to be divided equally to the distant parts of the country, which is divided into the nearest points.

Also, he has placed the condition of justice and consumes excessive extravagance, and has introduced it as one of the worst features of the unbelievers.

Islam has even considered justice to be necessary for worship, and it is also necessary to observe moderation in worship. To the extent that Imam Sadiq (AS) states: Late Kahrawa Eli Ansaf Almada. Do not put worship on yourself. Particularly in the training of children ordered to care for justice in their worship.

These descriptions and features have made Islam as the most complete divine religion as a religion of justice, and justice is considered as the basic condition of government and Islamic society.

In Islam, justice not only recommends friends and other Muslims that their observance during the war has also been ordered:

Fat Qatlukm Fatahtham Abdullah. If you kill your enemy, you also kill them. Yes, the punishment of those who disbelieve. Justice is killing here, and other than that, it's fear and zealot.

And I am killing the promise of the failure of Forelana Lolia Sultana Fla Yasrfi Fateh Allah. Whosoever is guilty of an innocent person is killed for his control, but the slave's parents are not allowed to take revenge.

Feminid al-Qa'id Qa'mdwa against us, like Al-Qum and Oqqullah.

Laynhah al-Qa'ul Al-Zahr al-Din al-Din al-Din al-Din al-Din al-Din al-Din al-Din al-Jahan, And, as a result, I would like to congratulate you on behalf of us.

And Lajar is not the son of the people Ali al-Adhlova.

According to Hayman, for the purpose of administering justice in Islam, there are various instruments and instruments that, in addition to the proper education and training of the sword, have also introduced revenge as a guarantor of justice.

\section{DEVIATIONS FROM JUSTICE}

Justice, as it was said, is rooted in human nature, and every human being requires justice in accordance with the human condition, but for some reason this natural feature may sometimes 
be forgotten. The Holy Qur'an has outlined some of the main reasons for the deviation from justice:

The first factor is the nature of the interests and relationships: either they are the guardians of the cono-Qavamis, and the martyrs are the chiefs of the martyrs, and they are the chiefs of the martyrs, and they are the riches of the poor, the first Fallah.

Those who believe have risen up to justice and your certificates are only for God, although you or your parents and relatives will end your losses and not be poor or rich in your testimony, because God is more deserving of having them Support.

This verse refers to the dangerous interests that lead to the exclusion of justice. The second cause of distraction from justice is the discomfort and dissatisfaction of certain individuals or groups that impede their rights: either they are responsible for the martyrdom of the martyrs, and they do not have the right to deny the right to vote. 0 you who believe, your plan is pure rebellion and just testimony. Ethnic hostility does not distort you from the border of justice and treat justice that is closer to virtue.

The third factor can be bribed and eating the property is forbidden and invalid. Vela Ocklava is the owner of the company

I am the owner of Alan Al-Hasham and Al-Qaeda.

Do not eat the property of one another with falsehood, and do not give part of it to the judges to eat part of the property of the people, while you know it is forbidden to seize it. The Qur'an introduces such factors as the grounds for leaving the border of justice, and believes that the establishment of justice requires a permanent and continuous monitoring of the affairs of society and the state, which is one of the most important ways of achieving this goal by virtue of the good and forbidding. .

\section{CONCLUDING AND CONCLUDING}

The study of the collection of authentic Islamic texts such as the Quran and the narrations of the Shiite Imams, as well as the opinions of the theologians and Muslim scholars, does not hesitate that justice is one of the largest and most important elements of Islam which, along with monotheism, prophethood, resurrection and Imamate, has a significant role in individual and collective approaches. Muslims have been determined in such a way that they determine the behavior of individuals and their interactions with each other is subject to internal and strict criteria, and on the other hand, the belief in religious government and the necessity of its realization and implementation will give it a new effect.

In this regard, the Shiites, based on their particular approach to justice and the importance and value they attach to it, have based their beliefs and values on justice in a fundamental way, and have tried to realize it to the brink of transgression.

This paper does not attempt to explain why this approach is descriptive due to its descriptive approach, and naturally this will be subjected to other writing.

\section{Sources and references:}

Holy Quran

Motahari Morteza, Divine Law, Islamic Publications, vol. 8, 1355

Dastgheib, Seyyed Abdul Hussein, Adl, Shiraz Educational Center, 1363

Qareati, Mohsen, Jalal and Social Justice, Islamic Publishers Office 
Sayyid Qottab, Social Justice in Islam, translated by Mohammad Ali Ghammi and Sayedadi Khosroshahi, Publishing Co. 1352

Mohammadi Ray Shahri, Mohammad, Adel in the Universe of Towhid, Center for Publications of the Islamic Propaganda Office, 1989

The rhetoric, Sadr al-Din, justice and justice in Islam, Amir Kabir, the fourth quarter, 1360

Haghi, Mohammed, The issue of justice and bribery from the perspective of Islam, Islamic Publications Office, QII, 1373

Qareati, Mohsen, Social Justice, Institute on the Right Way, Qom, Bicha, Bey

Leader, Mohammad Taqi, Political lessons from Nahj al-Balaghah, Amir Kabir, first year of 1364 